Piotr Brudnicki

\title{
TURBOKAPITALIZM - SZANSE I ZAGROŻENIA ROZWOJU W WARUNKACH GOSPODARKI WYSOKO ROZWINIĘTEJ
}

\section{Wprowadzenie}

Celem opracowania jest przedstawienie pojęcia i istoty turbokapitalizmu oraz możliwości i zagrożeń rozwoju w warunkach gospodarki wysoko rozwiniętej, a także ukazanie cech charakterystycznych „nowego kapitalizmu” w Stanach Zjednoczonych, skąd się wywodzi, i możliwych przesłanek dla Polski. Ważnym celem jest też przybliżenie i refleksja nad szansami i zagrożeniami, jakie niesie turbokapitalizm dla gospodarki światowej.

\section{Pojęcie $\mathrm{i}$ istota turbokapitalizmu}

Turbokapitalizm uważany jest za współczesną, znacznie rozwiniętą formę kapitalizmu, w której najważniejsza jest efektywność rynkowa pozbawiona jakiejkolwiek kontroli. Zysk ekonomiczny równoznaczny jest z zaspokojeniem potrzeb społecznych. Inaczej rzecz ujmując, to nic innego jak wolny rynek, na którym działają prywatne przedsiębiorstwa, wolne od regulacji rządowych, związków zawodowych dbających o dobro pracowników, barier podatkowych i celnych oraz ograniczeń inwestycyjnych.

Twórcą terminu jest amerykański ekonomista i statystyk Edward Luttwak z Centrum Badań Strategicznych i Międzynarodowych w Waszyngtonie. Po raz pierwszy użył on sformułowania „turbokapitalizm” w książce Turbokapitalizm: Zwycięzcy i przegrani światowej gospodarki. Według autora turbokapitalizm ${ }^{1}$ to forma kapitalizmu z „turbodoładowaniem”, któremu towarzyszą procesy prywatyzacji, globalizacji i deregulacji.

\footnotetext{
${ }^{1}$ E. Luttwak, Turbokapitalizm: Zwycięzcy i przegrani światowej gospodarki, Wydawnictwo Dolnośląskie, Wrocław 2000, s. 5.
} 
Każdej formie kapitalizmu towarzyszy wolny rynek - postrzegany jako szczególny rodzaj rynku, na którym wymiana dóbr dokonuje się w wyniku dobrowolnie zawieranych transakcji między kupującymi a sprzedającymi, przy dobrowolnie ustalonej przez nich cenie. Na wolnym rynku sprzedający i kupujący nie podlegają żadnym ograniczeniom ani przymusowi za strony podmiotów zewnętrznych (np. władzy publicznej), a warunki transakcji - szczególnie cena - są zależne jedynie od ich obopólnych ustaleń. Jedynymi warunkami wolnego rynku są określone prawa własności w odniesieniu do środków produkcji oraz dóbr wytworzonych. Wskutek tych uwarunkowań możliwy staje się do osiągnięcia zysk ekonomiczny rozumiany jako różnica między całkowitym przychodem ze sprzedaży określonego dobra a całkowitym kosztem ekonomicznym tego dobra²

Wyznacznikami turbokapitalizmu są: deregulacja, prywatyzacja i globalizacja. Turbokapitalizm cechuje przede wszystkim deregulacja ( $\mathrm{z}$ łac.) jako zmniejszenie oddziaływania państwa na ekonomiczną sferę kraju, czyli przede wszystkim na rynek; odbywa się to poprzez brak ingerencji w ustalanie cen oraz jakości dóbr i usług. Podążając tym tropem, jest to taki wpływ regulacji prawnych na linii pracownik pracodawca, który powoduje zniesienie lub obniżenie płacy minimalnej. Deregulacja jest powiązana ściśle z procesem liberalizacji gospodarki, a często i prywatyzacji.

W Polsce doskonałym przykładem jest zniesienie zakazu posiadania zagranicznych kont bankowych przez polskich obywateli, co ułatwiło swobodny przepływ kapitału.

Prywatyzacja jest aktem przekazania prywatnemu właścicielowi mienia państwowego; może się odbywać przez uwłaszczenie lub sprzedaż; można również wyróżnić podział na prywatyzację średnią i pośrednią (kapitałową).

Globalizacja to ogół procesów prowadzących do coraz większej współzależności i integracji państw, społeczeństw, gospodarek i kultur, czego efektem jest tworzenie się jednego świata, światowego społeczeństwa³ zanikanie kategorii państwa narodowego; kurczenie się przestrzeni społecznej i wzrost tempa interakcji poprzez wykorzystanie technologii informacyjnej ${ }^{4}$ oraz wzrost znaczenia organizacji ponad- i międzynarodowych, w szczególności transnarodowych korporacji ${ }^{5}$.

Proces globalizacji rozpoczął się już za czasów wielkich odkryć geograficznych. Towarzyszyła temu rewolucja w komunikacji społecznej dzięki odkryciu czcionki, prasy drukarskiej, co wpłynęło na skrócenie czasu dyfuzji kulturowej.

2 Makro- i mikroekonomia. Podstawowe problemy, red. S. Marciniak, Wydawnictwo Naukowe PWN, Warszawa 2005, s. 284.

3 M. Kempny, Globalizacja, w: Encyklopedia socjologii, Oficyna Naukowa, Warszawa 1998, s. 241.

4 A. Giddens, Socjologia, PWN, Warszawa 2004, s. 74-75.

${ }_{5}^{5}$ P. Sztompka, Socjologia zmian społecznych, Znak, Kraków 2005, s. 93-94. 
Turbokapitalizm to nowoczesny model kapitalizmu, którego wyznacznikiem, oprócz deregulacji, prywatyzacji i globalizacji, są zmiany technologicznej liberalizacji handlu. Jedynym czynnikiem kontroli jest skrupulatne przestrzeganie wskazań monetarystów.

Przez blisko pół wieku kontrolowany przez państwo kapitalizm zapewniał dynamiczny rozwój krajów Europy Zachodniej, Stanów Zjednoczonych i Japonii. Gwarantował on równocześnie wzrost zamożności i bezpieczeństwo socjalne mieszkańcom tych krajów. Były to w gruncie rzeczy różne odmiany wywierania przez państwo wpływu na gospodarkę.

W Europie model państwa opiekuńczego pozostawał obiektem tęsknoty ludzi zza żelaznej kurtyny i mieszkańców Trzeciego Świata.

Kapitalizm rozumiano jako system gospodarczy, który opiera się na wolnym rynku i jego ideologii. Powstał na skutek cywilizacji Zachodu i swoją efektywnością przewyższył inne systemy gospodarcze. Gospodarka kapitalistyczna jest więc skuteczna, sprawna, innowacyjna, a przy tym przydziela środki, efektywnie koordynuje zadania. Kapitalizm powoduje duże zmiany w systemie społeczno-politycznym poprzez gospodarkę wolnorynkową, która prowadzi do zastępowania tradycyjnych celów politycznych, społecznych i kulturowych celem ekonomicznym, czyli maksymalizacji zysku.

W kapitalizmie elementy wolnego rynku są poddane kontroli i ograniczeniom ze strony rządu. Natomiast w turbokapitalizmie nie ma kontroli i ingerencji państwa we wszelkie formy życia społecznego, ekonomicznego i gospodarczego.

Tabela 1. Podstawowe różnice kapitalizmu i turbokapitalizmu

\begin{tabular}{|c|c|}
\hline Kapitalizm & Turbokapitalizm \\
\hline $\begin{array}{l}\text { - Gospodarka sterowana, wspótistnieje przy silnym systemie } \\
\text { politycznym, którego zadaniem jest osiąganie określonych } \\
\text { celów społecznych. } \\
\text { - Elementy wolnego rynku poddane są kontroli } \\
\text { i ograniczeniom ze strony państwa } \\
\text { (władza ustawodawcza, wykonawcza, sądownicza). } \\
\text { - Państwo } \\
\text { - wspiera lub ogranicza niektóre gałęzie przemysłu } \\
\text { (bezpośrednio - finansowanie lub pośrednio - finanso- } \\
\text { wanie badań naukowych); } \\
\text { - ustala zakres importu i eksportu produktów, surowców } \\
\text { (cła, limity, bariery handlowe); } \\
\text { - reguluje warunki zatrudnienia; } \\
\text { - obejmuje opieką socjalną; } \\
\text { - dokonuje podziału dochodów (opieka społeczna, } \\
\text { medyczna, szkolnictwo). }\end{array}$ & $\begin{array}{l}\text { - Gospodarka wolnorynkowa, pozbawiona } \\
\text { jakiejkolwiek kontroli. } \\
\text { - Utożsamianie efektywności rynkowej ze } \\
\text { szczęściem społecznym. } \\
\text { - Dążenie do deregulacji (brak kontroli państwowej), } \\
\text { prywatyzacji (brak własności państwowej) } \\
\text { i globalizacji (otwarcie granic handlowych). } \\
\text { - Szybkie zmiany technologiczne i strukturalne } \\
\text { wpływają na sytuację polityczno-społeczną świata } \\
\text { - Przyczyną i skutkiem turbokapitalizmu jest } \\
\text { przesunięcie władzy w państwach } \\
\text { z politycznej na gospodarczą. } \\
\text { - Podporządkowanie społeczeństwa i państwa } \\
\text { jednemu ekonomicznemu celowi, } \\
\text { czyli maksymalizacji zysku. }\end{array}$ \\
\hline
\end{tabular}

Źródło: opracowanie własne na podstawie:.E. Luttwak, Zwycięzcy i przegrani światowej gospodarki, Wydawnictwo Dolnośląskie, Wrocław 2000 
Państwa, w których występuje kapitalizm, posiadają dość stabilną gospodarkę, cechuje je stałość w zatrudnieniu i dochodach, co daje poczucie wartości pozycji społecznej. Ludzie nawiązują trwałe relacje, zakładają rodziny. Rozwinięta opieka socjalna daje bezpieczeństwo jednostkom, które znalazły się $\mathrm{w}$ trudnej sytuacji. Tego typu gospodarka nie jest efektywna $\mathrm{z}$ punktu widzenia ekonomii, ale daje efekty społeczne: stabilizację życia ludzi, pewne jutro. Ludzie nie muszą ciągle walczyć o przeżycie lub żyć w nędzy.

Według Dahla kapitalizm „z regularnością i ładem” produkuje dobra i usługi, skuteczniej niż inne systemy ${ }^{6}$.

$$
\text { kapitalizm } \longrightarrow \text { dobrobyt } \longrightarrow \text { demokracja }
$$

Rozwój ekonomiczny sprzyja demokratyzacji i wyłania się klasa średnia, która stanowi podstawę do budowy liberalnej demokracji.

Dobrobyt ekonomiczny oznacza też lepszą edukację, co w połączeniu z rozwojem klasy średniej tworzy podstawy kultury obywatelskiej z towarzyszącym jej zaufaniem społecznym, zadowoleniem i kompetencjami.

\section{Rysunek 1. Rozwój ekonomiczny jako czynnik prywatyzacji}

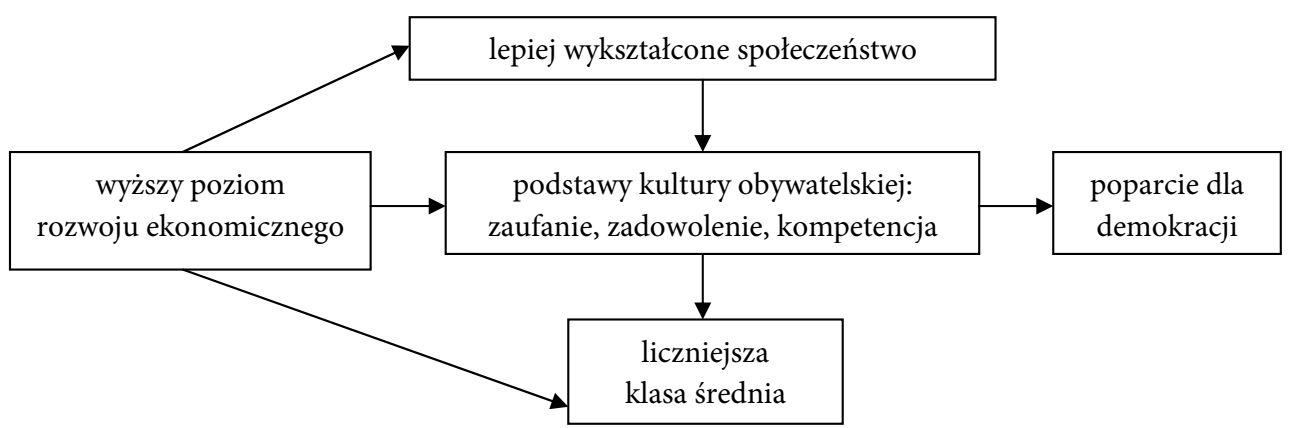

Źródło: S. Huntington, Trzecia fala demokratyzacji, PWN, Warszawa 2009.

Gospodarka rynkowa wymusza zatem rozwój mechanizmów negocjacji, zawierania porozumień i wypracowywania kompromisów ${ }^{7}$. Wszystko to odbywa się bez udziału państwa i stymuluje niezależność oraz samorządność jednostek i grup społecznych.

${ }^{6}$ S. Marciniak, Ekonomiczne aspekty globalizacji, Politechnika Warszawska, Kolegium Nauk Społecznych i Administracji, Warszawa 2002, z. 20, s. 7.

7 J. Sowa, Obywatele i konsumenci. Wolny rynek, demokracja i społeczeństwo obywatelskie w epoce turbokapitalizmu, „Problemy Polityki Społecznej” 2007, nr 10. 
Demokracja liberalna rozwinięta $\mathrm{w}$ krajach $\mathrm{z}$ gospodarką rynkową przetrwała dzięki świadomym i celowym ograniczeniom oraz regulacjom, jakie nałożono na wolny rynek. Brak jakiejkolwiek kontroli nie skutkowałby doprowadzeniem do wolności i dobrobytu, ale do niewolnictwa i monopolu.

Wartości społeczne i wolność osobista, równouprawnienie płci, ochrona zdrowia, powszechna edukacja czy równość szans nie zostały wypracowane przez kapitalizm, ale w dużym stopniu wymuszone przez świadomie i celowo działające ruchy emancypacyjne. Powszechny dobrobyt nie jest osiągnięciem rynku, lecz polityki.

Państwa opiekuńcze, które powstały w XIX w., nie są inicjatywą przedsiębiorców, lecz polityków (Bismarck, Disraeli). Wzrost gospodarczy i przyrost bogactwa może odbywać się dzięki nowym technologiom, szybkiemu przepływowi informacji, większej dostępności do środków transportu. Wyrównywalny podział dochodu sprzyja wzrostowi gospodarczemu poprzez stymulowanie popytu.

Na przestrzeni lat wykazano, że ważne jest nie tylko mnożenie wskaźników ekonomicznych, ale także budowanie stabilnego ustroju politycznego poprzez świadomą interwencję, ograniczenia i reformy. W kapitalizmie „bogactwo” wypracowane przez produkcję, handel i przedsiębiorczość wymusza rozwój aparatu administracji państwowej i silnego społeczeństwa obywatelskiego, które powinno chronić swojej wolności osobistej.

\section{Charakterystyka turbokapitalizmu}

Turbokapitalizm nastawiony jest przede wszystkim na maksymalizację zysku. Gdyby osiągnięcie tego celu zagwarantowało rozwiązanie problemów społecznych oraz zaspokojenie potrzeb obywateli, to turbokapitalizm stałby sie pożądanym systemem każdej współczesnej gospodarki ${ }^{8}$. Przeobrażenia, które wymusza turbokapitalizm w sektorze gospodarki rzeczowo-finansowej, widoczne są poprzez przyspieszenie tempa globalizacji procesów gospodarczych na międzynarodowych arenach; rozwój transnarodowych, potężnych korporacji.

Wzrost znaczenia ekonomicznego transnarodowych korporacji prowadzi do:

- deregulacji obowiązującego systemu rynkowego;

- osłabienia i marginalizacji autorytetu państwa oraz założeń społecznej gospodarki rynkowej;

- ograniczenia i łamania suwerenności walutowej i podatkowej;

8 S. Flejterski, „Zachodniopomorski Kurier Targowy” 2000, nr 78. 
- utraty sił ekonomicznych rządów narodowych, czego następstwem jest osłabienie dobrobytu społecznego, wzrost międzynarodowej przestępczości oraz terroryzmu.

Działanie korporacji transnarodowych, odgrywających ważną rolę na rynku finansowym i rynku pracy, doprowadza do sytuacji, w której pomnożenie zysków osiągane jest kosztem pracowników poprzez:

- obniżanie wynagrodzeń,

- utrzymywanie dotychczasowej wydajności pracy lub jej zwiększenie,

- natychmiastową utratę pracy,

- zwiększanie bezrobocia,

- zastępowanie stałej pracy przez dorywczą.

Podążając tym tropem, turbokapitalizm może wpływać na ekonomiczne efekty, tworząc wiele problemów społecznych i rosnące napięcia wśród obywateli, np.:

- ubóstwo,

- bezrobocie,

- wzrost nierówności,

- rozpad struktur społecznych,

- emocjonalną samotność jednostek.

Niestety, brak jest jakichkolwiek narzędzi, które mogą rozwiązać te problemy.

Niekorzystne zjawiska turbokapitalizmu może złagodzić silna i sprawna polityka, która powinna to zrobić nawet kosztem pomniejszonego zysku ekonomicznego.

Wspieranie „dobrobytu”, który jest naczelnym celem turbokapitalizmu, nie może być naczelnym celem polityki i społeczeństw, gdyż nie jest on równoznaczny ze szczęściem wszystkich obywateli, a tylko z poprawieniem sytuacji materialnej wybranych jednostek. Kontynuując tę myśl jest to sposób bogacenia się tylko niektórych obywateli w państwie, co prowadzi do ogromnych nierówności społecznych. Prywatyzacja jest przecież związana z likwidacją państwowych zakładów pracy, które dawały ludziom stałe i pewne zatrudnienie. Jednakże w jej wyniku wiele osób pozostaje bez pracy i środków do życia9.

Deregulacja systemu w konsekwencji może spowodować likwidację przepisów i osłon socjalnych, które wcześniej chroniły pracowników i „małych” pracodawców. Określały zasoby zatrudnienia, zwalniania i ramy odniesienia dla konkurencji. Jednakże w efekcie deregulacji łatwiej znaleźć pracę, ponieważ pracodawców nie ograniczają surowe reguły zatrudnienia, wysokie koszty siły roboczej i przepisy zwalniania pracowników. Niestety, deregulacji towarzyszy zawsze spadek zarobków i niepewność zatrudnienia. W złej kondycji znajdują się też „mali” przedsiębiorcy, którzy

9 A. Zorska, Ku globalizacji? Przemiany w korporacjach transnarodowych $i w$ gospodarce światowej, Wydawnictwo Naukowe PWN, Warszawa 1998, s. 260. 
skazani są (pod wpływem wielkiej konkurencji) na rezygnację z własnego biznesu lub na znaczne obniżenie kosztów funkcjonowania (zatrudnienie pracowników na gorszych warunkach, zwolnienia, obniżenie osłon socjalnych).

Globalizacja otworzyła granice handlowe między państwami, co w teorii zwiększyło możliwości zatrudnienia (dostęp do nowych rynków pracy). W praktyce znaczy to tyle, że otwierają się granice dla taniej siły roboczej i możliwość przenoszenia przemysłu w miejsca, gdzie praca jest tańsza.

W konsekwencji rośnie efektywność produkcji, ale spadają zarobki i jakość zatrudnienia (szczególnie dotyczy to klasy średniej) w krajach zamożniejszych. Turbokapitalizmowi zawsze towarzyszą zmiany technologiczne, dawne gałęzie przemysłu i przedsiębiorstwa z nimi związane upadają (zwolnienia dotyczą więc niewykwalifikowanych pracowników). Na ich miejsce powstają nowe ośrodki przemysłowe i przedsiębiorstwa, które nie są pracochłonne i dają zatrudnienie tylko wysokiej klasy specjalistom (rynek pracy ulega drastycznym zmianom).

Wypracowany przez gospodarkę ekonomiczny zysk w turbokapitalizmie dzielony jest w sposób nieproporcjonalny. Jego „wilczą" część dostaje mały procent ludzi, którzy znajdują się na szczycie. Bogaci zarabiają coraz więcej, a ubodzy coraz mniej. Niektórzy nie dostają nawet nic. W związku z tym pojawia się duża dysproporcja budząca niepokój społeczny, biedę i wzrost przestępczości. Przemiany gospodarcze generowane przez turbokapitalizm przyczyniają się do zmian w strukturach społecznych, takich jak luźniejsze więzi i układy rodzinne czy poczucie samotności, opuszczenia, niepewności jutra.

Konsekwencją tego jest zazwyczaj ucieczka w nałogi (alkohol, narkotyki, sekty namiastka dawnego życia we wspólnocie) lub w przestępczość (ukazanie sprzeciwu wobec istniejącego systemu).

Jednakże ci, którzy się bogacą, w dalszym ciągu głoszą ideologię wolnego rynku, który ma dać szczęście i dobrobyt wszystkim ${ }^{10}$. Niestabilność pracy, mniejsze zarobki, niepewność jutra, bezrobocie i bieda związane z funkcjonowaniem turbokapitalizmu wynikają więc $\mathrm{z}$ uwolnienia konkurencji i nagradzania tylko najefektywniejszych oraz towarzyszą efektywności gospodarczej, która nie jest tu problemem. Staje się nim jednak brak kontroli, ograniczeń i redystrybucji dochodów przez system polityczny, który każdemu człowiekowi zapewniałby minimum potrzebne do życia.

Musimy założyć, że to nie społeczeństwo ma służyć gospodarce, ale gospodarka społeczeństwu, gdyż inaczej konieczność redystrybucji wydawać się może nieuzasadniona. Przy takim założeniu potrzebna jest znowu zmiana systemu wartości z wolnorynkowego na społeczny.

10 J.E. Stiglitz, Globalizacja, Wydawnictwo Naukowe PWN, Warszawa 2004, s. 232. 
Turbokapitalizm przeniknął już do wszystkich grup społecznych, nawet do systemu wartości, co utrudnia możliwie mądre ograniczenia. Tylko świadoma walka z nim może dać efekty, gdyż niektóre społeczeństwa wierzą, że problemy społeczne, które wyzwolił turbokapitalizm, są naturalne, a przeciwstawienie się im jest niepotrzebne. Turbokapitalizm ma też wpływ na układy pomiędzy państwami. Nie oznacza to, że na świecie zapanuje wieczny pokój, oparty na światowym wolnym rynku, w którego ramach wszyscy będą dążyć do maksymalizowania ekonomicznego zysku. Powstanie nowy układ i geoekonomia, gospodarcza walka, w której ramach każde państwo będzie dążyć do zysku, ale przede wszystkim własnego. Dzieje się tak, ponieważ:

- w naturze państw leży konflikt i rywalizacja (państwa będą szukać nowych form konkurowania między sobą poprzez gospodarkę);

- rozwój turbokapitalizmu ograniczy rolę polityki, więc gospodarka zacznie decydować o pozycji państwa na świecie (władza gospodarcza jest pożądana i ma manipulować własną gospodarkę, aby ją wzmocnić i przewyższyć innych - jest to metoda walki z innymi państwami);

- wzrost zysku gospodarki w skali świata nie oznacza, że poprawia się sytuacja wszystkich państw uczestniczących w światowym systemie turbokapitalistycznym (widać tu analogię do wpływu wolnego rynku na sytuację poszczególnych obywateli).

Dlatego każde państwo, niezależnie od logiki wolnego rynku, dąży do wzmocnienia i obrony swojej pozycji w stosunku do innych ${ }^{11}$.

Państwo i tożsamość narodowa nie tracą na znaczeniu, nie powstaje globalna wspólnota, która jednoczyłaby ludzi. Jest to jeden z czynników, które mogą ograniczać turbokapitalizm. Państwa prowadzą politykę ekonomiczną, aby bronić swoich interesów w ramach światowego rynku, przedkładając ponad efektywność ekonomiczną świata wartość państwa i społeczeństwa. Konieczne jednak jest jeszcze ograniczenie turbokapitalizmu w skali państw, i to nie w celu walki z innymi, ale dla dobra wszystkich obywateli. W obronie interesów tych, których wolny rynek wypycha poza margines życia we wspólnocie, i w obronie tych, których sytuacja życiowa z pewnością nie należy do stabilnych.

Według E. Luttwaka działania polityczno-gospodarcze rządów, które są podejmowane podobno dla dobra wszystkich obywateli, prowadzą do bogacenia się niewielu wybranych szczęściarzy i najbogatszych państw świata. Maksymalizacja ekonomicznego zysku w skali państwa nie oznacza większego szczęścia przeciętnego człowieka, a w skali świata nie znaczy, że wzbogacą się wszystkie państwa. Należy

${ }^{11} \mathrm{http}: / / \mathrm{mfiles.pl} / \mathrm{pl} /$ index.php/Turbokapitalizm 
więc się zastanowić nad ograniczeniem rozwoju turbokapitalizmu, gdyż może on zagrażać w znacznym stopniu demokracji. Nie jest to kapitalizm drobnych kupców i wytwórców, których wychowali klasycycy liberalizmu. Jest on raczej wyposażony w wyrafinowaną maszynerię marketingu, reklamy, public relations, kapitalizm transnarodowych korporacji, monopoli, oligopoli i karteli, które ekonomiczną siłą przewyższają wiele państw. Zwolennicy tego nadliberalnego, globalnego turbokapitalizmu często powołują się na Adama Smitha. Zapominają jednak często, że to on przestrzegał wszystkich przed zagrożeniem dla wolności ze strony kapitalizmu korporacyjnego ${ }^{12}$.

Benjamin Barber twierdzi, że rozwój gospodarczy i wolny rynek można oddzielić od wolności politycznej, wskazując na przykłady Singapuru, Chin i Korei Południowej. Według niego idealny człowiek z punktu widzenia turbokapitalizmu, tzw. idealny obywatel mcświata, to oczywiście konsument. W rzeczywistości idealny konsument i dobry obywatel mają wiele sprzecznych i wzajemnie wykluczających się cech.

Tabela 2. Cechy dobrego konsumenta i dobrego obywatela

\begin{tabular}{|l|l|}
\hline \multicolumn{1}{|c|}{ Dobry konsument } & \multicolumn{1}{c|}{ Dobry obywatel } \\
\hline - Naiwny, bezkrytyczny - aby dało się nim skutecznie & • Kapryśny, niestały, powinien szybko się nudzić. \\
manipulować wykorzystując marketing i wzbudzać & - Podążający za pragnieniami, a po ich zaspokojeniu \\
w nim największą liczbę pragnień, które rynek może & poszukujący nowych. \\
zaspokoić. & • Zaprzeczenie konsumenta. \\
- Niezbyt wykształcony, ale nie głupi, bo to ograniczy & - Najlepiej wykształcony - droga do lepszego \\
ilość towarów, które kupi; powinien umieć czytać & społeczeństwa wiedzie tylko przez kształtowanie \\
i pisać, aby móc przyswajać sobie komunikaty & lepszych ludzi, a to można osiągnąć wyłącznie przez \\
reklamowe. & dobrą edukację. Edukacja jest podstawą postępu \\
- Ślepy na historię i żyjący w ,,ciągłym teraz”, by & ekonomicznego, gospodarczego i politycznego. \\
nie zorientował się, że „nowe” towary, do których & - Znający historię - orientujący się, w imię jakich \\
kupowania jest motywowany, to jednak ciągle to samo. & ideałów budowano świat i jakich wymagało to działań. \\
- Egoista i hedonista (powinien zaspokajać każdą & Altruista. \\
zachciankę bez dostrzegania kosztów zewnętrznych, & \\
np. zatrucia środowiska). & \\
\hline
\end{tabular}

Źródło: opracowanie własne na podstawie: J. Sowa, Obywatele i konsumenci. Wolny rynek, demokracja i społeczeństwo obywatelskie w epoce turbokapitalizmu, „Problemy Polityki Społecznej” 2007, nr 10.

W turbokapitalizmie bogatsi mają większe możliwości finansowania swoich interesów poprzez kampanie promocyjne, informacyjne, marketing polityczny czy lobbing, atomizację i prywatyzację oraz przedkładanie konkurencji ponad współpracę.

Według Georga Sorosa w neoliberalnym kapitalizmie wartości społeczne podlegają negatywnej selekcji; sukces odnoszą ci, którzy bez skrupułów i w bezwzględny

12 A. Ślęczka, Wcale nie oczywisty związek pomiędzy ekonomicznym zyskiem a dobrem człowieka i dobrobytem państwa, „Gazeta Uniwersytecka UŠ” maj 2002, nr 8 (97). 
sposób dążą do własnych korzyści ${ }^{13}$. Turbokapitalizm neguje jeden z planów zarówno demokracji, jak i społeczeństwa obywatelskiego: istnienie i rolę sfery publicznej. Zdaniem ideologów jest ona złem koniecznym, które trzeba jak najbardziej ograniczyć poprzez maksymalną prywatyzację. Rozwój sfery prywatnej, dającej kapitalistom możliwość maksymalizacji zysków, idzie w parze z zanikiem sfery publicznej ${ }^{14}$. Ma to na celu służenie większej wolności jednostki, co jest błędnym argumentem. Tylko pozornie turbokapitalizm daje nam coraz większe możliwości wyboru, a w rzeczywistości bardzo go ogranicza. Wspólne dobra, które znajdują się w sferze publicznej, służą w kapitalizmie przede wszystkim do ekstermalizacji kosztów akumulacji kapitału. W turbokapitalizmie działalność nastawiona na wspólne dobro, ochronę i rozwój sfery publicznej jest szkodliwa i „głupia”. Egoizm i chciwość to cnoty, a społeczeństwo to luźny zbiór jednostek, które nie mają względem siebie żadnych zobowiązań. Takie przekonanie niszczy ludzi i ich obywatelskość, która jest podstawą społeczeństwa i demokracji. Niszczy też bezpośrednio kapitał społeczny poprzez propagowanie ideologii, która jest anormalnym indywidualizmem.

Według socjologów i filozofów podstawowym problemem kapitalizmu są jego wewnętrzne sprzeczności. Ich dynamika i rozwój są niebezpieczne nie tylko dla demokracji, ale także dla kapitalizmu. To, co kapitalistom wydaje się wielkim sukcesem, w rzeczywistości może okazać się klęską demokracji i społeczeństwa obywatelskiego. Obywatelskość to pewien rodzaj więzi i świadomość współzależności, w której istnieje jednostka.

Rozwój kapitalizmu i wolnego rynku jako podstawowej siły promuje wizję człowieka samotnego, niepołączonego z nikim i z niczym. Ostatnią barierą, która oddziela jednostkę od rynku, jest rodzina. To, co dzieje się $\mathrm{z}$ więzią rodzinną, jest egzemplifikacją ogólnego rozpadu wszelkich więzi: zawodowych, towarzyskich czy sąsiedzkich.

„Rynek pracy wymaga mobilności niezależnie od osobistej sytuacji. Małżeństwo i rodzina potrzebują czegoś wręcz przeciwnego. W pełni przemyślany model współczesnego rynku zakłada społeczeństwo bez rodziny. Każdy musi być samodzielny i dyspozycyjny wobec wymogów rynku, aby zapewnić ekonomiczne podstawy egzystencji. Podmiotem na rynku w ostatecznej konsekwencji jest samotna jednostka, »nieskrępowana« związkiem rodzinnym, małżeńskim czy partnerskim”15.

13 B. Barber, Which technology for which democracy? Which democracy for which technology?, „International Journal of Communications Law and Policy” 2000/2001, Issue 6, s. 232.

14 J. Sowa, op.cit.

15 U. Beck, Społeczeństwo ryzyka. W drodze do innej nowoczesności, Wydawnictwo Scholar, Warszawa 2004, s. 37. 
W środowisku turbokapitalizmu troska o siebie jest jedynym i najważniejszym nakazem. Balastem natomiast jest troska o współobywateli i ich dobro. „W wysoce konkurencyjnym otoczeniu ludzie obciążeni troską o innych mogą działać mniej sprawnie niż ci, którzy są wolni od jakichkolwiek skrupułów moralnych, w ten sposób wartości społeczne podlegają czemuś, co można określić jako negatywną selekcję naturalną. Brak skrupułów pojawia się na szczycie. Jest to jeden z najbardziej niepokojących aspektów światowego systemu kapitalistycznego". Wykorzystując banał i naiwność, demaskując sferę publiczną kosztem hipertrofii tego, co prywatne, konsekwentnie ogłupiając obywateli, aby przekształcić ich w konsumentów i niszcząc więzi społeczne, kapitalizm niszczy demokrację w krajach rozwiniętych i rozwijających się. Skomercjalizowana kultura $\mathrm{z}$ wyjątkową siłą i potęgą kapitału wchodzi szybko i podstępnie w lokalne kultury, rujnując przy tym ich społeczne cnoty.

Przykładem tego negatywnego procesu są wydarzenia w Bhutanie. Kraj ten jako ostatni na świecie wprowadził telewizję. Bhutan to małe państewko położone wśród trudno dostępnych szczytów Himalajów (między Indiami, Chinami i Birmą). Zostało założone w XVII w. przez tybetańskiego mnicha, przez wiele wieków było najbardziej wyizolowanym miejscem na świecie. Do lat 50. naszego wieku nie było tu szkół, papierowych pieniędzy, elektryczności czy dróg. Pierwsze stosunki dyplomatyczne z innymi krajami Bhutan nawiązał w $1961 \mathrm{r}$. W roku 1974 z okazji koronacji po raz pierwszy zostali zaproszeni oficjalnie goście z Zachodu.

Później Bhutan też nie wprowadził globalnej gospodarki ani międzynarodowej turystyki. W ciągu roku na jego terytorium mogło wjechać tylko kilkaset osób (wykupując wcześniej drogie wizy - ponad tysiąc dolarów). Ta wyjątkowa izolacja w Kraju Grzmiącego Smoka (tak o Bhutanie mówią mieszkańcy) na przestrzeni stuleci nie zmieniła prawie życia mieszkańców. Typowe wartości buddyjskie: skromność, uczciwość, prostota, brak zainteresowania dobrami doczesnymi oraz czerpanie radości z małych spraw życia codziennego były oficjalnie promowane przez władze i powszechnie uznawane przez obywateli.

W roku 1988 władca Bhutanu podniósł je do rangi głównych cnót narodowych i ogłosił, że w przeciwieństwie do państw zachodnich, gdzie najważniejszy jest produkt krajowy brutto, społeczeństwo Kraju Grzmiącego Smoka ma dążyć do pomnażania szczęścia narodowego brutto. W tym kraju nie było McDonaldów, Coca-Coli, telefonów komórkowych i telewizji.

Dopiero w 1998 r. władca pozwolił na zainstalowanie w stolicy kraju gigantycznego telebimu, na którym wyświetlano transmisje mistrzostw świata w piłce nożnej we Francji. Rok później uruchomiono pierwszą publiczną telewizję. Trzy miesiące później uruchomiono sieć telewizji kablowej TV Star, która zaoferowała dostęp do kilkudziesięciu zachodnich stacji telewizyjnych. Król uważał, że wielowiekowe 
wychowanie uchroni naród przed negatywnym wpływem mediów. Mieszkańców ogarnął jednak obłęd zappingu. Naiwni i prości wieśniacy zostali takimi fanami reklamy, że w jednej z wiosek zbiory zgniły na polach, bo chłopi pogrążyli się $\mathrm{w}$ telewizyjnym nałogu.

W roku 2002 przeprowadzono badania, które ujawniły duże zmiany w świadomości społeczeństwa (rozjaśnianie włosów, skóry, przelotne związki). Około 35\% rodziców wolało oglądać telewizję, niż zajmować się dziećmi. Dzieci oglądały telewizję około 12 godzin dziennie.

W roku 2003 w państwie, w którym mieszkańcy od wieków opowiadali się za pacyfizmem i rzadko stosowali przemoc, odnotowano wzrost przestępczości. Pojawiły się wcześniej nieznane przestępstwa: gwałty pod wpływem alkoholu, prostytucja nieletnich, bezczeszczenie świątyń. Miejscem starcia dwóch różnych światów stała się szkoła. Nauczyciele musieli stawić czoło problemom społecznym, które stały się powszechne (chciwość, przemoc, zazdrość, znęcanie się nad słabszymi).

Dzieci żyją w dwóch światach: stworzonym przez szkołę oraz wykreowanym przez telewizję.

Jak łatwo zauważyć, na przestrzeni lat głównym mechanizmem dyfuzji kultury zachodniej jest zglobalizowana gospodarka, która często eksportuje to, co najgorsze i destruktywne.

\section{Możliwości i szanse rozwoju turbokapitalizmu}

Turbokapitalizm to totalnie wolny rynek, czyli kapitalizm z turbodoładowaniem ${ }^{16}$. Kapitalizm i jego nowe oblicze jako najbardziej efektywnego systemu nowożytnej ekonomii, jest połączeniem kapitalizmu korporacyjnego z kapitalizmem tzw. kasynowym.

Przejęcie własności publicznej przez prywatnych inwestorów (prywatyzacja) wywołuje negatywne emocje szczególnie w krajach postkomunistycznych. Wiąże się to $\mathrm{z}$ tym, że dawni biurokraci pozostają na swoich stanowiskach $\mathrm{z}$ wyższymi pensjami. Nawet wtedy, gdy są odpowiedzialni za kiepską politykę finansową i kondycję zakładu. Dzieje się tak często przy redukcji wielu wykwalifikowanych pracowników. Politycy (pod presją załóg) decydują się na szybką i nieprzemyślaną prywatyzację. Nie troszczą się o rezultat (często nie mają potrzebnej wiedzy prawnej i ekonomicznej), byle tylko wykazać się inicjatywą i dotrzymać złożonych pochopnie obietnic.

16 E. Luttwak, op.cit., s. 15. 
Turbokapitalizm jako forma kapitalizmu generuje ogromną efektywność, a w konsekwencji istotny postęp w wielu dziedzinach życia. Swobodny przepływ kapitału, wzrost efektywności i nowoczesne inwestycje w rejonach tradycyjnie zacofanych dają realną szansę zniwelowania olbrzymich dysproporcji między poziomem życia w krajach wysoko rozwiniętych i w zapomnianych „zakątkach” Trzeciego Świata czy w krajach postkomunistycznych. Egalitaryzm to fałszywie rozumiana równość, która prowadzi na rozdroża.

Problem jest bardzo złożony. Ludzie powinni zawdzięczać bogactwo własnej pracy, przedsiębiorczości, kwalifikacjom, umiejętnościom, talentom i wtedy to nie budzi niezadowolenia. Gdy jednak o sukcesie decydować ma przypadek, zachwianie niestabilnego rynku, decyzje podejmowane przez niekompetentnych pracowników, nieprecyzyjne przepisy, wtedy trudno o akceptację istniejącego porządku.

Wolny rynek jako jedyna siła sprawcza światowego ładu w dużej mierze ma charakter ideologiczny. Jak w krajach realnego socjalizmu wydajność jest tu niemal fetyszem $^{17}$. Ponadto zwycięska ideologia - podobnie jak kiedyś doktryna marksistowska - oferuje wszystkim bez wyjątku identyczne recepty, lekceważąc lub ignorując sferę tradycyjnych wartości, różnice społeczne, cywilizacyjne, obyczajowe. Ważna jest też mentalność społeczeństwa.

Rozwiązania kapitalizmu nie są w całości utopijne. Ich źródłem jest pragmatyczne podejście do rzeczywistości. Chłodna kalkulacja i czysty utylitaryzm bywają niekiedy mniej zgubne niż faktyczny idealizm. Nie można, jak zauważył już Adam Smith, arbitralnie kierować całą gospodarką. Można jednak korygować nieobliczalne następstwa oddziaływania rynku, przeciwdziałając rozkładowi tradycyjnych więzi społecznych.

W roku 1991 Jan Paweł II w encyklice Centesimus Annus poparł gospodarkę wolnorynkową najsilniej w dziejach Kościoła. Ostrzegł jednak, że działanie gospodarcze nie może odbywać się w próżni politycznej, prawnej oraz instytucjonalnej. Brak poczucia bezpieczeństwa, korupcja władz publicznych i niewłaściwe źródła wzbogacania się oraz łatwe zarobki, oparte na działaniach nielegalnych czy spekulacyjnych, są wielką przeszkodą dla porządku i rozwoju gospodarczego.

Trzeba powiedzieć, że łączna wartość transakcji zawieranych na światowych giełdach kilkanaście razy przewyższa wartość wytworzonego tego samego dnia globalnego produktu brutto. Nie można więc tu mówić o jakiejkolwiek stabilności. Pozytywne jest szybkie powstawanie nowych fortun. Dzieje się to dzięki nowym technologiom, postępowi technicznemu, ale równocześnie powoduje olbrzymie zmiany w strukturze zatrudnienia. Następuje redukcja miejsc pracy, obywatele tracą poczucie bezpieczeństwa.

17 J. Sowa, op.cit. 
Po zakończeniu zimnej wojny polityka straciła wiele na znaczeniu w stosunku do ekonomii. Demokracja wobec zaniku społeczeństwa obywatelskiego staje się swego rodzaju osłoną przed faktem, że pewne rozstrzygnięcia są w coraz większym stopniu dziełem technokratyczno-finansowych elit, które nie liczą się z polityką społeczną. Nie ponoszą one jakiejkolwiek odpowiedzialności, spadającej na polityków.

Szef Bundesbanku Hans Fietmayer na forum gospodarczym w Davos powiedział: „Większość polityków nie zdaje sobie sprawy z tego, jak dalece znajdują się pod kontrolą rynków finansowych i są oczywiście przez nie sterowani”. Recepty prezesów banków centralnych (Bank Światowy, MFW, FED) są zawsze takie same. Zalecane są w szczególności:

- deflacja,

- ograniczenie wydatków rządowych,

- rygorystyczny budżet,

- polityka „trudnych” kredytów ${ }^{18}$.

W kategoriach ekonomicznych ma to swoje oczywiste uzasadnienie. Banki $\mathrm{z}$ reguły dyscyplinują gospodarkę i starają się zapobiec nieprzewidzianym wstrząsom. Jednak to, co w ekonomii niby jest oczywiste, może wpływać niezwykle negatywnie i destrukcyjnie na wszystkie relacje społeczne.

Przykłady można wymieniać z przeszłości:

- Adolf Hitler doszedł do władzy na skutek bezwzględnej polityki finansowej (recesja w Niemczech), nie słuchał finansistów i osiągnął „cud gospodarczy”, za który „rachunek" wystawiła II wojna światowa;

- Roosevelt (New Deal) i jego reakcja na kryzys, sprzeciwienie się ówczesnemu sposobowi myślenia o gospodarceo okazało się skutecznym „lekarstwem na recesję i stagnację";

- „wilczy kapitalizm” i marksistowska krytyka nierówności społecznych, która z walki klas zrobiła doktrynę i zmobilizowała ogromne rzesze ludzi nieposiadających własności radykalizując ich oczekiwania.

Rewolucja informatyczna, która dokonuje się na naszych oczach, niesie też bardzo podobne, ale o wiele większe zagrożenia. Rewolucja przemysłowa potrzebowała bardzo dużo rąk do pracy, co powodowało wielkie migracje. We współczesnym świecie mamy do czynienia z ciągle rosnącą liczbą ludzi „niepotrzebnych i niechcianych”. To właśnie na początku XX w. w Rosji lisznieje ludi (zbyteczni ludzie) stali się główną siłą napędową bolszewickiego przewrotu. Poczucie beznadziejności i desperacja nie są rodzajem motywacji, która umożliwia rzetelną i obiektywną ocenę swego położenia.

18 Forum Gospodarcze w Davos. 
Słabość ekonomii w XX w., liczne aberracje w świecie polityki doprowadziły do tego, że miliony ludzi zapłaciło straszną cenę za przetrwanie innych. Kapitalizm jest poza bronią nuklearną najpotężniejszym wynalazkiem człowieka. Przeniknął prawie do każdej części świata. Zysk i ekspansja to naturalne ambicje każdego kapitalisty. Jednakże niektóre metody, które się upowszechniły, nie są właściwe ${ }^{19}$. Praktykuje się nagłe, masowe zwolnienia z pracy zamiast łagodniejszych wypowiedzeń, które mogą kosztować tylko trochę więcej (czasem tańsze) - tylko dlatego, że ceny akcji zwyżkowały, a menedżerowie mogli osiągnąć szybkie zyski. $Z$ tych samych powodów zamykano zakłady decydujące o zatrudnieniu w całej okolicy, bez próby poprawy ich kondycji. Szybki zysk zastępuje korzyści większe, ale realizowane w późniejszym terminie, ponieważ menedżerowie wciąż szukają najbardziej atrakcyjnych korporacji, a długofalowych przedsięwzięć jest coraz mniej.

W rezultacie życie jednostek, rodzin, społeczności, a nawet całych regionów ulega rozkładowi i ruinie. Bezlitosne statystyki pokazują, że zwalniani tracą dużo więcej niż miejsca pracy. Ich długość życia maleje na skutek stresu i upokorzenia, następuje rozpad rodzin, niespłacone domy przestają być ich własnością. Niepewne miejsca pracy, nawet dobrze płatne, nie dorównują jakościowo bezpiecznej, stałej pracy z perspektywą awansu. Podtrzymują one bieżącą konsumpcję, ale nie dają perspektywy na przyszłość. Korporacje nie odważyłyby się zniszczyć środowiska naturalnego (ogromne sankcje pieniężne), ale szkodzą środowisku ludzkiemu bez żadnych konsekwencji.

Zadaniem rządów powinno być znalezienie środków i narzędzi, które sprawowałyby kontrolę nad kapitalizmem w interesie obywateli. Społeczeństwo oczekuje, by rząd je reprezentował. Najwyższym priorytetem rządu musi być znalezienie środków zaradczych przeciwko zniszczeniom spowodowanym przez kapitalizm poza dopuszczalne granice. Od końca II wojny światowej do połowy lat 70. gospodarka w Stanach Zjednoczonych i Europie rozwijała się bardzo szybko, przynosząc dostatek niewielu, a potem wszystkim ${ }^{20}$. Nie tylko w niektórych regionach Europy, ale także w Japonii dziedziczone niegdyś ubóstwo ustąpiło miejsca stale rosnącemu dobrobytowi.

Koniec lat 70. przyniósł zmianę tendencji do sterowania gospodarką. Ważną rolę w demontażu amerykańskiego systemu regulacji odegrały moda i ideologia ${ }^{21}$. Ważniejszy stał się dobrze opłacany lobbing na rzecz zainteresowanych stron, które miały najwięcej zyskać na deregulacji.

W Stanach Zjednoczonych czy w innych krajach europejskich międzynarodowa konkurencja sprawiła, że poprawa jakości lub obniżka kosztów wymusiły tempo

19 S.J. Adamski, Pieniądze i więż, „Kwartalnik” 2000, nr 9.

20 E. Luttwak, op.cit., s. 7.

${ }^{21}$ Ibidem, s. 14. 
deregulacji danego przemysłu w innych krajach. Żadne państwo nie mogło powstrzymać tego procesu, nie przyłączając się do deregulacji gospodarki, chyba że byłyby w stanie płacić koszty takiej decyzji (np. Francja, Japonia). W latach 70. XX w. dzięki tym działaniom wielu ludziom za oceanem powiodło się. Wykorzystali zaoferowane im możliwości. Inni zyskali dzięki prywatyzacji, a niektórzy odnieśli łatwy sukces w tradycyjnych gałęziach przemysłu, dzięki „wysokiej fali rynków akcji” (upadek przedsiębiorstw, zakup po zaniżonych cenach - podobnie odbywało się to w Polsce, Rosji i innych krajach postkomunistycznych). Nagradzane są wybitne osiągnięcia, ale i miernota, jeśli trafi się na pobłażliwą dyrekcję. Dyrektor Green Tree Financial w 1996 r. zajął pierwsze miejsce na liście najlepiej zarabiających dyrektorów (roczna pensja 102449000 dol., czyli 280682 dol. dziennie, licząc weekendy i urlopy) oraz na liście najmniej skutecznych dyrektorów w tworzeniu wartości dodanej dla udziałowców. W tym samym czasie około $60 \mathrm{mln}$ mniej „zaradnych Amerykanów” pracujących w fabrykach stanęło przed groźbą bezrobocia. Wielu ludzi utraciło posady w przemyśle, w biurach i sytuacja zmusiła ich do podjęcia pracy fizycznej w handlu, usługach, ochronie, przewozach, sprzątaniu (podobnie stało się w Polsce tylko około 15 lat później i w innych krajach Europy). W ten sposób zaczęli się zsuwać w dół, zajmując wszystkie stanowiska klasy niższej. Zwiększyła się przestępczość. Związek przyczynowy między turbokapitalizmem a przestępczością towarzyszy przyspieszonym zmianom technologicznym i strukturalnym, które wyeliminowały wiele miejsc pracy w miastach przemysłowych (w Polsce - w Łodzi po „upadku” tkalni nastąpił wzrost prostytucji, alkoholizmu, rozpad rodziny itp.).

W przeszłości w fabrykach zatrudniano niewykwalifikowanych robotników, którzy po znalezieniu pracy zaistnieli w gospodarce. Potem już sama siła inercji utrzymywała posadę i szacunek otoczenia ${ }^{22}$.

W miarę przekształceń gospodarki (deregulacja, prywatyzacja, globalizacja) przy likwidacji wielu miejsc pracy nie wszyscy umieli się odnaleźć i poszukać swojej "niszy ekonomicznej” wśród oszałamiających okazji oferowanych przez turbokapitalizm. Około $50 \mathrm{mln}$ Amerykanów żyje w coraz większym dostatku. Turbokapitalizm okazał się dużo mniej skuteczny dla ogromnej większości społeczeństwa. Najwyżej zarabiający otrzymują coraz większą część ogólnych dochodów. Coraz więcej jest też gospodarstw domowych jednoosobowych (tzw. single).

Bogaci Amerykanie biorą odsetki od bilionowych depozytów, obligacji i pożyczek hipotecznych. Jednakże łączne oszczędności Amerykanów są bardzo małe, więc zadłużenie Stanów Zjednoczonych rośnie i wynosi tyle, ile kilkuletni wzrost gospodarczy całego kraju. Amerykańska elita dobrze przyjmuje obcych inwestorów, sama

22 S. Flejterski, Ekonomia globalna. Synteza, Difin, Warszawa 2003, s. 291. 
inwestuje za granicą, korzystając z wyższych stóp procentowych, dywidend lub bezpośrednich zysków i głęboko wierząc w konieczność eliminowania wszelkich przeszkód dla wolnego rynku (globalizacja). Przekonując inne państwa, że celem ich istnienia jest tylko prowadzenie gospodarki, amerykański turbokapitalizm ruszył na podbój świata. Dotarł do Wielkiej Brytanii (Margaret Thatcher uważała go za swój wynalazek), Niemiec, Grecji, rozwijających się krajów Azji, państw latynoamerykańskich, wschodniej Europy aż po Moskwę.

Tylko we Francji i Japonii próbuje się bronić starych metod, aby móc zapewnić miejsca pracy, odpowiednie pensje.

Od Wielkiej Brytanii po Argentynę, od Skandynawii po Nową Zelandię przybywa nowych multimilionerów, ale i nowej wielkiej biedy. Są to bezrobotni lub ci, którzy pracują w niepełnym wymiarze godzin, ci bez wykształcenia, którzy kiedyś mieli pewne posady, hojnie wynagradzani przez państwo, teraz są zatrudnieni przez prywatnego właściciela za mniejsze pensje i bez jakichkolwiek przywilejów. Stany Zjednoczony opanowały cały świat od młodzieżowej mody do polityki na wysokim szczeblu ${ }^{23}$.

Jednakże tradycjonaliści w Europie i Azji mają za złe amerykanizację swoich krajów i swoich dzieci. Najsilniejsze reakcje na turbokapitalizm wywołuje niedoskonałe, a tym samym niebezpieczne ich naśladowanie, a nie ich bezkrytyczna akceptacja. Turbokapitalizm wpływa na wzrost ekonomiczny, a wszystkie jego siły napędowe: deregulacja, prywatyzacja i globalizacja przyspieszają rozwój sektora finansowego. Prywatyzacja przyniesie „kiedys'” zysk, ale sama nie daje nowych maszyn, budynków, technologii, siły roboczej. Wymaga jednak od razu wielu działań finansowych: trzeba dokonać sekurytyzacji aktywów prywatyzowanej firmy (akcje, obligacje), sprzedać je, wziąć i dawać kredyty bankowe, zdobyć pieniądze na sfinansowanie projektu. Deregulacja ma ułatwić wolną konkurencję, która zwiększy efektywność zużycia zasobów ludzkich i rzeczowych.

Przedsiębiorstwa „uwolnione” od wielu przepisów szybciej korzystają z usług finansowych. Niektóre formy globalizacji nie zwiększają produkcji, a tylko przenoszą produkcję z kraju do innego kraju. Wymagają więc obrotu walutami i związanego z nim obrotu kontraktami typu futures oraz swaps zabezpieczającymi przed ryzykiem kursowym.

Wraz z nadejściem turbokapitalizmu rozpoczął się rozwój różnego rodzaju giełd, banków, dużo szybszy niż obiektów potrzebnych typu sklepy, fabryki itp. ${ }^{24}$ Firmy, które nie emitowały nigdy akcji, zaczynają teraz to robić. Powstają domy makler-

23 Globalizacja i regionalizacja w gospodarce światowej, pr. zb., PWE, Warszawa 2011.

24 J. Tittenbrum, Gospodarka w społeczeństwie, Wydawnictwo Zysk i S-ka, Warszawa 2012. 
skie, giełdy papierów wartościowych, dilerzy walutowi itp. To wszystko wymusza chwalenie „dobrych przepisów” i instytucji przestrzegania prawa (inspektorzy, kontrolerzy, prokuratorzy, którzy mają egzekwować prawo, banków, klientów itp.).

Turbokapitalizm małymi krokami wkroczył też do krajów postkomunistycznych, w których utrzymują się niektóre bariery inwestycyjne, importu oraz konkurencji, wyjątkiem są Czechy, Estonia, Łotwa, Polska i Węgry. W wyniku szybkiej transformacji Federacja Rosyjska od 1994 r. wprowadziła gospodarkę rynkową. Swobodny rozwój turbokapitalizmu prowadzi do rozpadu społeczeństwa na małą grupę zwycięzców, wielu przegranych o zróżnicowanym stopniu zamożności, a także biedy i buntowników łamiących prawo. Zniszczeniu ulega poczucie społecznej wspólnoty, więzi rodzinnych, gdyż coraz bardziej zagrożeni ludzie przestają ją pielęgnować, chcąc nadążyć za wprowadzanym kapitalizmem. Jeśli pozwoli się, by turbokapitalizm przekształcił wszystkie instytucje - szkoły, wydawnictwa, szpitale do „biegów długodystansowych" - w przedsiębiorstwa, które maksymalizują zysk, to ich ekonomiczna wydajność może poprawi się, ale istota ulegnie zniekształceniu, a w konsekwencji wypaczeniu.

Przeciwdziałanie tym zmianom prowadzi jednak do zubożenia, a nawet zaniku tych instytucji w społeczeństwie, które nie będą w stanie się utrzymać, gdyż zostaną pokonane przez gospodarkę. Społeczeństwo służy gospodarce, a nie gospodarka społeczeństwu - to naczelna zasada turbokapitalizmu. Jeśli cały kapitał lokowany jest w jednostki, które przynoszą największy zysk, to nie zostanie nic na sfinansowanie instytucji, które zajmują się słabszymi jednostkami. Niestety wszyscy politycy ignorują oczywisty logiczny wniosek, że turbokapitalizm przyspieszy rozbicie społeczeństwa na bohaterów z Doliny Krzemowej i padół rozpaczy.

W porównaniu z niewolnictwem wymarłej gospodarki komunistycznej, bezdusznego socjalizmu biurokratycznego i groteskowym upadkiem gospodarki nacjonalistycznej turbokapitalizm bezwzględnie przewyższa je pod względem materialnym, zaś moralnie na pewno nie jest gorszy mimo wszystkich swoich niszczących wpływów na społeczeństwo, rodzinę i kulturę. Jednakże zgoda na jego panowanie nad każdym aspektem życia, od sztuki do sportu wraz z całą gospodarką, nie może być szczytowym osiągnięciem ludzkości. Również turbokapitalizm może kiedyś przeminąćc ${ }^{25}$.

25 E. Luttwak, op.cit., s. 276. 


\section{Zakończenie}

Po zapoznaniu się ze zdaniem Luttwaka, który przedstawia turbokapitalizm jako proces bogacenia się niewielu wybranych szczęściarzy i najbogatszych państw świata, istotne wydają się założenia odnośnie do negatywnego wpływu turbokapitalizmu na społeczeństwo oraz sferę realną gospodarki. Zagrożenia są dużo większe niż szanse, gdyż maksymalizacja ekonomicznego zysku w skali państwa dla przeciętnego człowieka nie oznacza większego szczęścia. Bogacenie się tylko nielicznych warstw społecznych może doprowadzić do sporych dysproporcji w stosunku do ludzi mniej przedsiębiorczych. Maksymalizacja ekonomicznego zysku w skali świata nie jest równoznaczna $z$ bogaceniem się wszystkich państw. Zasadne staje się więc ograniczanie tej tendencji w celu wyrównywania szans społeczeństwa.

\section{Słowa kluczowe:}

turbokapitalizm, wolny rynek, zysk ekonomiczny, deregulacja, prywatyzacja, globalizacja, kapitalizm, problemy społeczne, dobrobyt, zmiany społeczne, kapitalizm korporacyjny, dobry obywatel, dobry konsument

\section{Keywords:}

turbo-capitalism, the free market, economic profit, deregulation, privatization, globalization, capitalism, social problems, welfare, social conversion, corporate capitalism, exemplary citizen, exemplary consumer

\section{Turbo-capitalism - opportunities and threats in the development of highly developed economy}

This paper acquainted readers with the concept of turbo-capitalism as a form of capitalism. The person who precisely define this is Edward Luttwak, term of turbo-capitalism through free markets, privatization, globalization and deregulation. The paper set the basic differences between capitalism and turbo-capitalism. Economic stability and job security is for the individual "better tomorrow". The development of technology and faster flow of information should promote economic development and economic progress of modern states. I would like to draw 
the attention on the fact that turbo-capitalism is focused on maximizing profits, which does not solve social problems. National governments are losing economic strenght and, consequently, reduces social welfare and does not prevent crime and terrorism. Multiplication of turbo-capitalism profits leads to the increase of unemployment and therefore social pathology. This paper shows that the wellbeing, which is the main objective of turbo-capitalism, could not be the main goal of politics and society as it improves the material status of a few individuals, while it does not bring happiness to the majority. My work in this area is a "voice" of the wise limitations of turbo-capitalism, because this process uncontrolled can lead to the destruction of mankind. I tried to show that turbo-capitalism is the greatest threat to democracy. Capitalism could not focus on the individual, because it leads to "loneliness" of people in a wide range. In my work I have acquainted the reader with the situation created in Bhutan, during the inventions of civilization. I had presented in this work opportunities for Third World countries through the free movement of capital, modern technologies and investments. The reader has to understand, however, that the information revolution brings very big threat to humanity. The Industrial Revolution leads to rapid growth in employment and decline of information technology indicators at one time. The reader should learn from the negative effects of the American turbo-capitalism and help to develop positive qualities.

\section{Турбокапитализм - шансы и угрозы для развития в условиях высокоразвитой экономики}

Целью статьи является познакомить читателей с понятием турбокапитализма как особой формой капитализма. Автор названия - Эдвард Люттвак, связывал турбокапитализм со свободным рынком, приватизацией, глобализмом и дерегуляцией. В разработке определены основные различия между капитализмом и турбокапитализмом.

Стабильная экономика и гарантия занятости это для человека лучшее будущее. Развитие технологии и более быстрый поток информации должны благоприятствовать экономическому развитию современных государств. В моей работе я показал читателю, что турбокапитализм это прежде всего максимизация прибыли, которая не решает социальных проблем. Национальные правительства утрачивают экономические силы, а в результате снижается общественное благосостояние, вырастают преступность и терроризм. Множение прибыли в турбокапитализме ведет к росту безработицы, и тем самым социальной патологии. 
В статье указано, что благосостояние, которое является основной целью турбокапитализма, не может считаться главной целью политики и общества, так как улучшает экономическое положение нескольких человек, но не дает счастья большинству. Ведет к разбогатению немногих и обеднению множества людей. Быстро растет социальное неравенство.

Работа является призывом к ограничению турбокапитализма, потому что неконтролируемый он может привести к гибели человечества. Выявлено, что турбокапитализм становится самой большой угрозой для демократии. Капитализм не может сосредоточиться на личности, потому что это приводит в широком диапазоне к „одиночеству” людей.

В своей работе я ознакомил читателя с ситуацией возникшей в Бутане после внедрения цивилизационных изобретений, а также представил возможности для стран третьего мира связаны со свободным движением капитала, современных технологий и инвестиций. Однако, читателю надо понимать, что информационная революция несет в себе очень большую угрозу для человечества. Промышленная революция привела к быстрому росту занятости, в то время как информационная к его спаду. Из-за быстрых технологических изменений общество находится под угрозой в связи с быстрым ростом безработицы. Читатель должен сделать выводы на будущее по поводу негативных последствий американского турбокапитализма, чтобы способствовать развитию только его положительных черт.

\section{Le turbo-capitalisme - les opportunités et les menaces du développement dans une économie hautement développée}

Dans cet article, l'auteur utilise le terme «turbo-capitalisme» qui constitue un cas particulier du capitalisme. Le créateur de ce terme est Edward Luttwak, qui le définit en se référant au marché libre, à la privatisation, à la globalisation et à la déréglementation. Larticle montre les différences fondamentales entre le capitalisme et le turbo-capitalisme. L'économie stable et la sécurité d’emploi signifient pour l'individu un avenir meilleur. Le développement technologique et le flux croissant d'informations devraient encourager le développement économique des Etats modernes. Lauteur montre que le turbo-capitalisme se concentre principalement sur la maximisation du profit économique, ce qui ne résout pas les problèmes sociaux. Les gouvernements nationaux perdent leur potentiel économique et, par conséquent, la prospérité sociale diminue et la criminalité et le terrorisme augmentent. La prospérité, qui est lobjectif principal du turbo-capitalisme, ne peut pas être l'objectif principal de la politique et de la société, car elle améliore la situation 
économique de quelques individus. Les inégalités sociales augmentent. Le turbocapitalisme est la plus grande menace pour la démocratie. Le capitalisme ne peut pas se concentrer sur l'individu, car une telle situation conduit à la «solitude» de personnes dans un large éventail.

Lauteur présente la situation au Bhoutan après l'introduction des inventions de la civilisation dans ce pays. Il montre les opportunités du développement des pays du Tiers-Monde à travers la libre circulation des capitaux et des technologies modernes, ainsi quà travers des investissements. La révolution de l'information porte une très grande menace pour l'humanité. La révolution industrielle a entraîné une croissance rapide de l'emploi et la révolution de l'information conduit à sa réduction. En raison des changements technologiques rapides, le taux de chômage augmente, ce qui ne sera pas favorable à la situation sociale. 